\title{
PATTERNS OF LANGUAGE USE AMONG MULTILINGUAL UNIVERSITY STUDENTS MAJORING IN ENGLISH
}

\author{
Emi Nursanti, Erna Andriyanti, Paulus Kurnianta, Titik Sudartinah \\ Universitas Negeri Yogyakarta \\ email: eminursanti@uny.ac.id
}

\begin{abstract}
As a multilingual country, the Indonesian government has set the positions of local language, national language, and foreign language in education through Law of National Education System No.20 of 2003, Chapter VII, Article 33. Fifteen years passed and this paper seeks to find the results of the law in higher education students by investigating the patterns of language use of multilingual students in English Literature Study Program of FBS UNY. This is a descriptive study with parallel mixed method design. The data in this study were responses upon questions in the questionnaires distributed to respondents where the results were then analyzed quantitatively by using SPSS (17) and the results of interviews were analyzed qualitatively. The source of data in this study were 162 respondents who were students of English Literature study program, Faculty of Languages and Arts, Universitas Negeri Yogyakarta year 2015-2017. The results show that at home, more than $60 \%$ of students use Javanese with intimacy and habit as motivating factors. As English Literature students, they are more exposed to media in Bahasa Indonesia. On the campus, English is only used for academic purposes, Bahasa Indonesia for communicating with lecturers while Javanese is for a casual talk with classmates. Javanese is close to traditional commerce while for the modern one, they prefer to use Bahasa Indonesia. For cognitive and mental activities, Bahasa Indonesia is the most dominant, and Javanese is used more than English. These results imply that rather than conforming to the law made by the government, contexts play a more important role in forming people's language choices.
\end{abstract}

Keywords: multilingualism, local language, national language, foreign language, English Literature UNY

\section{POLA PENGGUNAAN BAHASA MAHASISWA MULTILINGUAL JURUSAN BAHASA INGGRIS}

\begin{abstract}
Abstrak
Sebagai negara multibahasa, pemerintah Indonesia telah menetapkan posisi bahasa daerah, bahasa nasional, dan bahasa asing dalam pendidikan melalui UndangUndang Sistem Pendidikan Nasional No.20 tahun 2003, Bab VII, Pasal 33. Lima belas tahun telah berlalu dan tulisan ini berupaya untuk menemukan penerapan hasil hukum tersebut pada mahasiswa dengan menyelidiki pola penggunaan bahasa mahasiswa multibahasa di Program Studi Sastra Inggris FBS UNY. Ini adalah penelitian deskriptif dengan metode campuran paralel. Data dalam penelitian ini
\end{abstract}


adalah tanggapan mahasiswa terhadap pertanyaan dalam kuesioner yang hasilnya kemudian dianalisis secara kuantitatif dengan menggunakan SPSS (17) serta hasil wawancara yang dianalisis secara kualitatif. Sumber data dalam penelitian ini adalah 162 responden yang merupakan mahasiswa program studi Sastra Inggris, Fakultas Bahasa dan Seni, Universitas Negeri Yogyakarta angkatan tahun 2015-2017. Hasil penelitian ini menunjukkan bahwa di rumah, lebih dari $60 \%$ mahasiswa menggunakan bahasa Jawa dengan keakraban dan kebiasaan sebagai faktor pendorongnya. Sebagai mahasiswa Sastra Inggris, mereka lebih terpapar media dalam Bahasa Indonesia. Di kampus, bahasa Inggris hanya digunakan untuk tujuan akademik, Bahasa Indonesia untuk berkomunikasi dengan dosen, dan bahasa Jawa untuk percakapan santai dengan teman. Bahasa Jawa sangat dekat dengan perdagangan tradisional, sedangkan untuk perdagangan modern, mereka lebih memilih untuk menggunakan Bahasa Indonesia. Untuk kegiatan kognitif dan mental, Bahasa Indonesia adalah yang paling dominan, dan bahasa Jawa digunakan lebih dari bahasa Inggris. Hasil ini menyiratkan bahwa alih-alih menyesuaikan ketentuan yang telah dibuat oleh pemerintah, konteks memainkan peranan yang lebih penting dalam membentuk pilihan bahasa penggunanya.

Kata kunci: multilingualisme, bahasa daerah, bahasa nasional, bahasa asing, Sastra Inggris UNY

\section{INTRODUCTION}

People are now living in the global era where the rapid development of information technology makes them able to reach the world just in a few seconds. Geographical boundaries no longer exist as they can meet and talk with people from other countries easily. Then becoming multilingual is one of the effects. Multilingualism refers to somebody's ability in using two or more languages (Edwards, 2003; Meyerhoff, 2006; Wei, 2008). The same definition refers to bilingualism (Auer, 1995; Bathia, 2006; Grosjean, 1985; Romaine, 1995). Some other linguists use the terms bilingualism and multilingualism based on the number of languages, two or more than two, in the context of their study (Cenoz \& Gorter, 2011; Dorian, 2006; Spolsky, 2003). In this study, multilingualism is used as in the first definition although there is a possibility that most participants in this study master at least three languages: local language, Bahasa Indonesia, and English.

Multilingualism is a language phenomenon found in many places around the world since almost all countries are multilingual (Bhatia \& Ritchie, 2006; Dorian, 2006; Edwards, 2006; Wei, 2008). A country is called multilingual when there is an official admittance on the use of at least two languages there. Besides, the multilingualism of a country is reflected from the use of two or more languages there although officially the country admits one language only.

As multilingualism is considered important, especially concerning the maintenance of languages spoken by minority groups to avoid language loss, 
currently the study of multilingualism is supported by some international organization, like UNESCO (Lim, 2009: 52; UNESCO, 1953, 2003, 2016) and the European Union (Franceschini, 2011: 345).

Indonesia is a multilingual country. The Indonesian language policy related to multilingualism is embodied in the Law of National Education System No.20 of 2003, Chapter IIV, Article 33. It states "1) Bahasa Indonesia as the language of the nation shall be the medium of instruction in the national education. 2) Local language can be used as a medium of instruction in the early stage of education, if needed in the delivery of particular knowledge and/or skills; 3) A foreign language can be used as a medium of instruction to support the competency of the learners." With the existence of those three languages, this law tries to say that multilingualism principle refers to three levels, 1) local languages as a way to maintain tradition and local identity, 2) Bahasa Indonesia as the official and national language, and 3) foreign languages as an asset to face global challenges. Based on this principle, ideally, multilingualism in Indonesia heads towards forming multilingual people who have local wisdom, nationalism, and global competitiveness.

However, in practice, people choose the language they use differently from what the principle expects. Language use in a multilingual context is related to language choice in a certain situation and domain. Studies on language usage by a multilingual community often found certain patterns and it is normal as choices in using language are not random. Choosing a certain language in a communication process is often based on the surrounding context, like the topic, interlocutor, as well as the setting of place and time. We call those contexts as language domain. It refers to some activities, socio-cultural constructs, or contexts viewed as a unity of place, topic, and relationship among the speakers (Romaine, 1994: 43; 1995: 30; Spolsky, 2003: 34). Some domains of language use are home, school, government, commerce, and religion. Some other new domains occur as the rapid development of technology (UNESCO, 2003).

The underlying concept for conducting this study is that students of the English Literature Study Program of UNY are young people who grow up in the multilingualism culture of Indonesia and specifically study English language and literature and it is assumed that they can be ideal multilingual people. However, there is a tendency in their group to use local language at home, Bahasa Indonesia in campus, and English in limited academic scope. This paper will explore that phenomenon.

\section{METHOD}

This study used explanatory sequential mixed method design which involved twosteps, collecting quantitative data and their analysis in the first step, and analyzing qualitatively in the next step. The purpose of employing this research design is to give more accurate and deeper interpretation qualitatively on findings of quantitative analysis (Creswell, 2014: 224). The data of this study were responses of questions in the questionnaire distributed to respondents and the result of the interview with some respondents who were selected randomly. 
The participants in this research were 162 university students from different academic years at English Literature Study Program, Faculty of Languages and Arts, Universitas Negeri Yogyakarta. 82.7\% were born in Javanese-speaking cities or regencies and $11.1 \%$ were not. $19.1 \%$ were men, $80.2 \%$ were women and $0.6 \%$ ( 1 student) did not answer the question. $7.4 \%$ live in housing estates in Yogyakarta City, $10.5 \%$ live in housing estates outside Yogyakarta City, 2.5\% live in highway side of Yogyakarta City, 7.4 live in intercity highway side, $22.2 \%$ live in villages in Yogyakarta City, 22.7\% live in villages outside Yogyakarta City, 27.2\% live in villages in the countryside, and 1 student did not answer the question. $78.4 \%$ are from the Javanese tribe, $16.1 \%$ are from mixed-tribe where $6.8 \%$ of them are from Javanese father and non-Javanese mother while 9.3\% of them are from Javanese mother and non-Javanese father, and 1 student did not answer the question.

The quantitative instruments used in this study were questionnaires distributed to all participants and SPSS 17 to process the data while the qualitative instrument was interview guide to explore deeper information from the respondents related to the result of questionnaire tabulation.

With the parallel mixed-method design, the collection and analysis of both quantitative and qualitative data were conducted separately which then integrated into the findings (Hesse-Biber, 2010). While producing descriptive statistics using SPSS was the first step of analyzing the quantitative data, the qualitative data were firstly condensed by creating categories and writing analytic notes on the data chunks and then displayed in organized information (Miles, Huberman, \& Saldana, 2014). Then, the last step was drawing conclusions for both the quantitative and qualitative analyses.

\section{RESULTS AND DISCUSSION Results}

By referring to the three levels of multilingualism principle mentioned earlier, it is necessary to relate the students' patterns of language use with the contexts where each language is commonly used: local language which is closely related to home domain, Bahasa Indonesiaas the nationallanguagewhich links to their communication habit in public places both in offline and online modes, and English as their major of study which is related to their campus life, including the references that they read. Besides, since the language used by people shapes the way they think, it is also necessary to see the language choice in their psychological domain. Therefore, several contexts that become the base in categorizing the students' language use are home, media, campus, public places. and mental domain.

One thing to consider in describing the language use at home is the students' hometown where most of them $(82.7 \%)$ were born in Javanese-speaking cities or regencies and only a few of them (8 students or $4.9 \%$ ) came from nonJavanese parents. Thus, Javanese is the language used by most of their family members.

Generally, the pattern of language use in the family and home environment among English Literature students is shown in Table 1. 
Table 1. Pattern of Language Use of English Literature Students of FBS UNY in Home Domain

\begin{tabular}{lccccccc}
\hline $\begin{array}{c}\text { Language to } \\
\text { communicate with }\end{array}$ & Mother & Father & Siblings & $\begin{array}{c}\text { Relatives } \\
\text { and niece/ } \\
\text { cousin }\end{array}$ & $\begin{array}{c}\text { Peer- } \\
\text { group }\end{array}$ & $\begin{array}{c}\text { Older } \\
\text { neighbors }\end{array}$ & Guests \\
\hline Javanese Krama & $\sqrt{ }$ & $\sqrt{ }$ & & & & $\sqrt{ }$ & $\sqrt{ }$ \\
Javanese Ngoko & $\sqrt{ }$ & $\sqrt{ }$ & $\sqrt{ }$ & $\sqrt{ }$ & $\sqrt{ }$ & & $\sqrt{ }$ \\
Bahasa Indonesia & $\sqrt{ }$ & $\sqrt{ }$ & $\sqrt{ }$ & $\sqrt{ }$ & $\sqrt{ }$ & $\sqrt{ }$ \\
\hline
\end{tabular}

It is seen that Javanese Krama which is closely related to courtesy is never used to talk among youth in the same age (siblings, relatives and niece/ cousin and peer-group) while Javanese Ngoko, which is associated to intimacy is never used to talk to people in a distant relationship (older neighbors and guests).

Related to language use in media, the research findings show that students are more exposed to Bahasa Indonesia in various mass media, either printed, audio-visual or online, and communication media such as SMS, phone call, and email as well as a social network. The use of English is under Bahasa Indonesia where the frequency is categorized as seldom.

On the campus, English is the dominant language relevant to the references or class assignments in
English Literature Study Program. The use of English by most of the lecturers in delivering materials in both skill and theory classes is admitted by most of the respondents. It is by $92.6 \%$ of students for skill subjects and $80.2 \%$ of students for theory subjects. The use of English by lecturer lowers in classes of concentration package. It is mostly because the content of the course is more difficult so that the lecturers tend to deliver the material bilingually or by mixing the codes of English and Bahasa Indonesia. However, for general courses given to all university students regardless of their study program, the material delivery is dominated by the use of Bahasa Indonesia. The language use pattern of the lecturers in specific courses related to English Literature study program is shown in Table 2.

\section{Table 2. Language Use Pattern of Lecturers in English Literature Study Program of FBS UNY}

\begin{tabular}{lc}
\multicolumn{1}{c}{ Type of course } & Language use by the lecturer \\
\hline Language skill courses (same for all students) & English \\
Theory courses on language and literature (same for all students) & $\downarrow$ \\
Courses in concentration package & Bahasa Indonesia \\
\hline
\end{tabular}

Patterns Of Language Use Among Multilingual University Students Majoring In English ～～ 235 
The down arrow in that table shows the big percentage of English usage in some courses on language skills, which then lowers in the theory and concentration package courses. The language used by students to lecturers in class shows that only $54.3 \%$ of them use English and 42.6\% use Bahasa Indonesia. Outside the classroom, most of them $(80 \%)$ use Bahasa Indonesia to communicate to lecturers, the head of the study program, staff, and employees in the campus environment.

The public place domain in this study is limited to the commerce and entertainment domain since those are the two most visited public places for the respondents. The findings of language use in public places, especially to transact and communicate to tourists, show that most students choose to use Javanese to communicate in traditional commerce, such as traditional market and small stall in their neighborhood, and use Bahasa Indonesia in more modern commerce, like malls or stores at the roadside. Using Bahasa Indonesia by most of the students is also found when they talk to ticket sellers in cinema and tourism objects.

The general pattern of students' language use in public places in the commerce and entertainment domain is shown in Table 3.

Table 3. The pattern of Language Use of English Literature Students of FBS UNY in Public Places

\begin{tabular}{lcccccc}
\hline \multirow{2}{*}{ Language } & \multicolumn{2}{c}{ Traditional commerce } & \multicolumn{2}{c}{ Modern commerce } & \multicolumn{2}{c}{ Entertainment } \\
& Market & Neighboring stall & Shop & Mall & Cinema & Tourism object \\
\hline Javanese & $\sqrt{ }$ & $\sqrt{ }$ & & & & \\
Bahasa Indonesia & & & $\sqrt{ }$ & $\sqrt{ }$ & $\sqrt{ }$ & $\sqrt{ }$ \\
\hline
\end{tabular}

In answering the questionnaire on communicating with foreign tourists, $88.9 \%$ of students admit that they use English, while to have interaction with domestic tourists, $95.7 \%$ of them choose Bahasa Indonesia.
For mental activities, based on the research findings, the general patterns of students' language use in the private psychological domain can be illustrated in Table 4.

Table 4. The pattern of Language Use of English Literature Students of FBS UNY in Inner Speech

\begin{tabular}{lrrr}
\hline \multirow{2}{*}{$\begin{array}{c}\text { Language in the } \\
\text { mental domain }\end{array}$} & \multicolumn{2}{c}{ Cognitive } & Cognitive-emotional \\
\cline { 2 - 5 } & Counting & Serious thinking & Inner speech \\
\hline Bahasa Indonesia & $68.5 \%$ & $59.3 \%$ & $38.3 \%$ \\
Javanese & $25.3 \%$ & $28.4 \%$ & $32.7 \%$ \\
English & $3.1 \%$ & $8 \%$ & $23.5 \%$
\end{tabular}


The down arrow shows the lowering percentage of language use from Bahasa Indonesia to English. Cognitively, the use of Bahasa Indonesia is more dominant compared to Javanese or English; and Javanese is used by more students in the cognitive process compared to English.

In cognitive-emotional aspects, the arrow goes down as well but it shows less percentage starting from the use of Javanese to Bahasa Indonesia. This implies that Bahasa Indonesia is dominant while English is least likely used by the students. However, the number of students is significantly different if it is compared to the activities involving the cognitive domain only.

Table 5. The pattern of Language Use of English Literature Students of FBS UNY in Mental Emotional Domain

\begin{tabular}{lc}
\hline $\begin{array}{c}\text { Language in the } \\
\text { mental domain }\end{array}$ & $\begin{array}{c}\text { Emotional } \\
\text { Give vent to emotions }\end{array}$ \\
\hline Javanese & $42.0 \%$ \\
English & $30.2 \%$ \\
Bahasa Indonesia & $21.0 \%$ \\
\hline
\end{tabular}

Javanese which, for the speakers, is often related to feelings, like the relationship of speakers and politeness values, is chosen by most students as a means to express their emotions. Meanwhile, English is used more than Bahasa Indonesia because they do not want to be too obvious in expressing their emotions.

\section{DISCUSSION}

\section{Language use in the home domain}

Based on the responses of the questionnaire, most participants use
Javanese to speak to parents and siblings as well as to older neighbors and people of the same age. Bahasa Indonesia is chosen to communicate with cousin or niece from a distance and to guests.

The interview reveals the reasons for language choice in the family and home domain. The choice of using Javanese is based on the intimacy between the speakers and Javanese is their mother tongue (S1, S2, S4, S6, S7, S8, S9, S12). Some of them use the high level of Javanese (Krama) with their parents or older neighbors (S2, S4, S6). Some say that they use Krama because they live in a village.

Bahasa Indonesia is used with guests (S1, S3, S4, S6, S9, S12) because guests are interlocutors they do not know or because they are not sure whether the guests can speak Javanese or not (S2). Some students use Bahasa Indonesia to communicate with family members. Two of the reasons are because they have used Bahasa Indonesia since they were children (S3, S7) or because one of their parents is not from Java. Nevertheless, they use Javanese with their peer group (S3). Using Bahasa Indonesia to everyone at home is also done by those whose families live in non-Javanese areas (S5).

The choice of using Javanese with family and people at home is related to their habit since children as it is their mother tongue and it shows the intimacy between them and their interlocutor. The low level of Javanese (Ngoko) is considered able to represent informality and intimacy.

As for me, it creates an effect of intimacy if I use Javanese. For me, using Bahasa Indonesia is, more formal, in my opinion. Thus, to 
make myself feel closer to others, I use Javanese. (S3)

It's like a different context. I use Javanese if I want to be flippant because the Javanese I use is not the one which ... so it's not.. not formal. (S7)

The use of a local language other than Javanese to show intimacy is also admitted by S11, who, since he was a kid, uses Bahasa Indonesia to communicate with his parents but chooses to use Bengkulu language with his brother.

With my brother, I use the Bengkulu language. It is because we are nearly of the same age. (S11)

An interlocutor becomes an important determining factor. Some students in the interview state that they try to suit the language chosen by their interlocutor as what is described by S10.

I sometimes use Bahasa Indonesia since the person living in front of my house is from Jogja and he speaks Bahasa Indonesia with me but using Javanese with my mom. It's like I am confused about why it should be different. (S10)

Adjusting language to the one used by the interlocutor also happens in the context of receiving a guest as what is described by S5 and S12.

Bahasa Indonesia, unless the guest invites me to use Javanese. In that situation, I try to use Javanese as well. (S5)

Initially of course I use Bahasa Indonesia, but if the guest wants to use another language: to use Javanese, then I do so, to use the Sundanese, I will do too. (S12)
S5 is from Java but Bahasa Indonesia is his mother tongue. S12 is from a place in Central Java borders on West Java. He feels he is not good at speaking Javanese politely thus he chooses to always use Bahasa Indonesia when he has to communicate with a guest for the first time. However, when the guest indicates that he/she wants to use another language, as Javanese or Sundanese, S12 will try to suit it.

In this family and home environment, Bahasa Indonesia is chosen because of their unfamiliarity with the interlocutors. For example, when a student has to communicate with a guest coming to their home, like what was told by S12, or when the speaker considers that using Bahasa Indonesia will create fewer mistakes compared to Javanese (Krama) which is sociolinguistically used because of distance factor or respect to the interlocutor.

The use of Bahasa Indonesia is also related to habit and neighborhood where most of the residents are nonJavanese people.

When I am at home, I always use Bahasa Indonesia to anyone because the language there is Bahasa Indonesia. Javanese is also used, but it's seldom. Yes, my family members are from Java, but it is more multicultural there. I mean like, there are people from Java, from Banjar, from Manado, and so on. So it's better to use Bahasa Indonesia. (S5)

S3 is a student whose parents are from Java, but his family members do not live there. He states that he always uses Bahasa Indonesia with all his family members, friends, neighbors, and 
guest as Bahasa Indonesia is his mother tongue and it is been the habit of his family as well as most of the people in his neighborhood to use Bahasa Indonesia.

From this explanation, it can be concluded that the home domain is not always related to the local language. There are several factors causing speakers to not using their local languages in their local areas, such as their inability to fluently use the high variation of the local language and the multicultural neighborhood situation.

\section{Language use in the media domain}

That the students of English Literature UNY rarely access English mass media or non-textbook materials is quite disappointing since those media are essential resources that can accelerate their English learning as well as give additional knowledge on the language and culture of people from English speaking countries. This means most students tend to rely on the learning resources given by teachers in their classrooms.

The findings on the high frequency of Bahasa Indonesia use by students of English Literature UNY in telecommunication media are like that of Andriyanti (2016) who researched middle school students in Yogyakarta. Although students are now in the digital era and global communication with very high technology advancement, their social network and interaction are so limited. This is related to the small number of students who have friends from foreign countries which should be an important connection to support their ability in communicating with foreign people by using international language.

The finding that more students use Javanese to communicate through phone calls and SMS compared to those who use English is reasonable, especially related to their intimacy and relation to their peer group. Based on the research findings, most students are Javanese people with Javanese surroundings. Thus, their schoolmates as well as their peer groups are also from Java. "With whom? If it's only classmates, I often use Javanese. What's on the campus is a Javanese environment, you know?" (S7). Besides, Javanese is considered to be able to represent their emotion when it is used in a call or SMS. "If Javanese can show emotions, like happiness, anger, sadness, I use Javanese most of the time." (S6). In the context of calling or sending messages, students also try to follow the language choice of the interlocutor, as stated by S9 in the following.

So, I tend to follow people, which means for the first time I invite people to use Bahasa Indonesia then later when he uses Javanese, then I reply by using Javanese. So I tend to follow the person I'm talking to. If he uses Javanese, I do so. If he uses Bahasa Indonesia, I also use Bahasa Indonesia. (S9)

Related to social media, more students say that they prefer English to Javanese.

On my Instagram, I use English more frequently than Bahasa Indonesia. Moreover when I want to allude to someone, I use English; moreover when the one is from English Literature. (S4) 
It's kinda often, most frequently, right now, by using English. It's because if we make online status, we sometimes represent our feelings, right? It's easier to express. (S8)

The reason underlying the choice of using English is related to their status as students of English Literature. They want to show their language proficiency that is relevant to their discipline and English is considered more prestigious compared to Javanese. They mention some terms to refer to this as 'cool' which means good or 'funny' which for young people, especially girls, means 'good or cool'. Another reason is that they want their posted status can be understood by people knowing English or understood by more people as English covers more than the scope of local and national. S6 says, "As its coverage is broader, so whoever reads it knows it." and S10 uses the word "universal" to describe the coverage of English.

\section{Language use on campus}

The low level of English usage in the campus domain implies that even the campus environment cannot be an environment that supports the use of English for most students of English Literature of UNY. An example of one interesting point is that there is a lecturer who does not motivate the students, who are still learning a foreign language, to use English.

I once, with Mr. X, tried to use English, but then at one word, I forgot the English of that word and then I switched to Bahasa Indonesia. Then Mr. X said, "If you use English, use full English, don't mix it." (S1)
There is also a student who feels uneasy when he is going to use English to talk to lecturers (S2). Some students just follow the general habit as the lecturers also do not use English in communication outside the classroom. Besides, using Bahasa Indonesia makes communication between lecturer and student more casual (S4). "Outside the classroom, I always use Bahasa Indonesia to make it more friendly." (S5)

Most students of English Literature UNY (more than 90\%) state that they do not use English to communicate with their classmates, either in or outside the classroom. "Using English with classmates outside the classroom brings an 'awkward' impression" (S1). However, using Javanese outside the classroom, makes communication smooth and the conversation more casual. "If we are not in the classroom, we use Javanese more as it's more casual." (S4)

\section{Language use in public places: commerce and tourism}

When the participants were asked about the language they choose to communicate with sellers in a traditional market, five students state that they use Javanese concerning flexible prices and bargaining system (S2, S4, S5, S6, S7). S11 says that he uses his local language in talking to sellers at a traditional market in his home town which is not in Javanese island.

"I use Javanese in the traditional market to get a cheap price." (S6)

It's because when I use Bahasa Indonesia, the sellers will think that I'm a newcomer then they will raise the price. My mom told me that "If 
you're in a traditional market, don't use Bahasa Indonesia" so I use Javanese though not the Krama one. I know that's impolite but what else can I do? (S7)

Another student says that she uses Javanese based on the general custom in the market she used to shop and relates it to the education level of the sellers in a traditional market.

It's not for underestimating but it's real. The sellers in a traditional market are 'grassroots' (wong cilik), so maybe their education level is not as high as those taking higher education, so I prefer to use Javanese. Moreover, I go to a traditional market in Wonosari and most of them are Javanese, so I suit the place and the people. (S10)

Another reason for using Javanese to communicate to sellers in a traditional market is to make them intimate or closer (S3, S5) or to maintain courtesy (S3, S12).

When I'm in a traditional market, I use Javanese. Though I can't speak the Krama, I try to. It looks forced, as I'm a comer in Jogja; but whether I want it or not, I have to respect the custom by using Javanese outside.

Some students state that compared to Javanese, Bahasa Indonesia is more appropriate, more prestigious, and practical to use in modern commerce (S1, S2, S4, S7, S8, S10). Concerning language use in cinema, S7 says, "It's like what I said, Bahasa Indonesia is more prestigious. Javanese makes me show my Javanese accent, and it's plebeian, right? That's my view." Meanwhile, some opinions on language in the mall are as follows.
Maybe it's because it's been settled in our mind that Bahasa Indonesia is more prestigious. Like I said, in a traditional market, I use Javanese while in a department store, I use Bahasa Indonesia. I think that's the reason. (S8)

If it's in a mall, they are middle to upper-class people, so I must use Bahasa Indonesia, I use Bahasa Indonesia more frequently. (S4)

The dominant use of Bahasa Indonesia in modern commercial places shows language symbolism (see Errington, 1998: 4). Contrasted to Javanese, Bahasa Indonesia is a symbol of modernity, and shopping in a mall has been a lifestyle of modern people (see Gerke, 2002). The use of Bahasa Indonesia by most students of English Literature UNY (97.5\%) in shopping centers like malls reflects their dream to be a part of the modern lifestyle of those from the middle to the upper class. This finding supports the research result of Smith-Hefner (2009: 62).

To communicate with ticket seller in a tourism object, nine students choose to use Bahasa Indonesia because it is more practical, fast, and must be understood by the interlocutor. Meanwhile, one student has an additional answer.

It depends on the kinds of tourism objects. If it's like Gembira Loka or the bigger ones, I use Bahasa Indonesia. But, for ticketings like spring or other small tourism objects, I usually use Javanese. The reason why I use Bahasa Indonesia in Gembira Loka is respect. But it's kind of different and I don't know when I'm in a place like in spring, I use Javanese though I can't do that. It's because I respect Javanese 
people or Jogja people because they use Krama language when they're not at home, but mine is a mix of Krama-Indonesia. (S3)

For communicating with foreign tourists, almost all respondents prefer to use English. Choosing English is based on the students' assumption that probably foreign tourist cannot understand Bahasa Indonesia, and without looking at their countries, English should be used first (S1, S2, S3, S4, S5, S7) as English is the lingua franca (S5), universal language (S6), or standard language for foreigners (S8).

\section{Language use in the psychological domain}

Within thiscontext, moststudentsuse Bahasa Indonesia. The factor assumed to be underlying the significant use of Bahasa Indonesia is students' education process which involves the language to be the main delivery language. Another factor is the strong influence of Javanese as their mother tongue, which shapes the habit of cognitive activity by using this language.

The students' admittance in the interview related to the use of Bahasa Indonesia for cognitive purposes is to make them easier and faster in doing those activities (S1). It is easier because of habit or because Bahasa Indonesia is their mother tongue (S2, S5, S9, S11, S12).

By using Bahasa Indonesia, it's easier to get... the idea is faster to come. (S1)

Satu dua tiga. It's like... it's been here... something inner.. something innate. It's been accustomed. (S5) It's a habit since I was a kid. Satu dua tiga. (S9)
Javanese (Ngoko) wasin second place. It is used to count and think seriously as it is easier and more comfortable (S3, S7); it has been accustomed since that language is the mother tongue (S4, S10); and it unconsciously happens (S6, S10).

My brain works in Javanese as well. Siji loro, never satu dua tiga, never. It's been innate. My mother tongue is Javanese, so automatically I use Javanese. (S4)

I don't know, it's just more comfortable, ji ro lu, compared to tu wa.. tu wa ga pat. (S7)

Based on the interview result, Javanese is chosen to vent their emotions because it is stronger (S1, S7), or it already becomes their habit (S10). The view that local language is more appropriate to vent emotions is also admitted by $\mathrm{S} 11$.

In a lot of anger, until I need to swear, I usually use Javanese. It's more emotional when I use Javanese, especially the East Java dialect. The emotion is released. I don't know why. (S7)

It's just stronger. It's because the Bengkulu language is a bit harsh. So, it challenges the emotion, the adrenaline. (S11)

While English is rarely used by the respondents for inner speech as it needs adequate language competence (Fahy, 2014) and it is formed by their habit which does not use English for daily communication, more students choose to use English to vent emotion since it can hide an overflowed emotion (S5, S9) because the expressions used are considered 'cool' (S6). One student admits that in swearing, he uses English because it is not vulgar (S9). 


\section{CONCLUSION}

The multilingualism principles in Law of National Education System No.20 of 2003, Chapter IIV, Article 33 which consist of three: 1) using local languages to maintain tradition and local identity wealth, 2) Bahasa Indonesia as the official and national language, and 3) foreign languages as an asset to face global challenges are not fully realized in the practical language use of English Literature students of FBS UNY. Instead of conforming to those principles, the factors motivating the language they choose are contexts, such as the setting of place and the interlocutor, habit, prestige, and easiness. In this study, Javanese shows intimacy for its low variant (Ngoko) and respect for its high variant (Krama); Bahasa Indonesia characterizes modernity while English represents a prestige and no boundary.

\section{REFERENCES}

Andriyanti, E. (2016). Multilingualism of Hhigh School Students in Yogyakarta, Indonesia: The Language Shift and Maintenance Tesis S3. Sydney: Macquarie University.

Auer, P.(1995). The Pragmatics of CodeSwitching: A Sequential Approach. In L. Milroy \& P. Muysken (Eds.), One Speaker. Two Languages: Crossdisciplinary Perspectives on Codeswitching (pp. 115-135). Cambridge: Cambridge University Press.

Bathia, T. K. (2006). Introduction. In T. K. Bathia \& W. C. Ritchie(Eds.), The handbook of bilingualismBlackwell Handbooks in Linguistics (pp. 1-2). Oxford: Blackwell Publishing.

Bhatia, T. K., \& Ritchie, W. C. (2006). Introduction. In T. K. Bhatia \&
W. C. Ritchie (Eds.), The handbook of bilingualism (pp. 1-2). Malden: Blackwell Publishing.

Cenoz, J., \& Gorter, D. (2011). Focus on Multilingualism: A Study of Trilingual Writing. The Modern Language Journal, 95(3), 356-369. doi: 10.1111/j.1540-4781.2011.01206.x

Creswell, J.W. (2014). Research Design: Qualitative, Quantitative, and Mixed Methods Approaches. California: SAGE Publications.

Dorian, N. C. (2006). Minority and Endangered Languages. In T. K. Bhatia \& W. C. Ritchie (Eds.), The handbook of bilingualism (pp. 437459). Malden: Blackwell Publishing Ltd.

Edwards, J. (2003). Multilingualism. London: Taylor and Francis.

Edwards, J. (2006). Foundations of Bilingualism. In T. K. Bathia \& W. C. Ritchie (Eds.), The handbook of bilingualism (pp. 7-31). Oxford: Blackwell Publishing.

Errington, J. J. (1998). Shifting Languages: Interaction and Identity in Javanese Indonesia. Cambridge: Press Syndicate of the University of Cambridge.

Fahy, J.K. (2014). Language and Executive Functions: Self-talk for Self-Regulation. Perspectives on language learning and education. 21(2):61. DOI: 10.1044/ 1le21.2.61

Franceschini,R.(2011).Multilingualism andMulticompetence:AConceptual View. The Modern Language Journal, 95(3), 344-355. doi: 10.1111/j.15404781.2011.01202.x

Gerke, S. (2002). Global Lifestyles under Local Conditions: the New Indonesian Middle-Class. In B.-H. 
Chua (Ed.), Consumption in Asia: Lifestyle and identities (hal. 135-158). London and New York: Routledge.

Grosjean, F. (1985). The Bilingual as a Competent but Specific-Hearer. Journal of Multilingual and Multicultural Development, 6(6), 466-477. doi: 10.1080/01434632.1985.9994221

Hense-Biber, S. N. (2010). Mixed Methods Research: Merging Theory with Practice. New York: The Guilford Press.

Lim, L. (2009). Beyond Fear and Loathing in SG: The Real Mother Tongues and Language Policies in Multilingual Singapore. AILA Review, 22(1), 52-71. doi: 10.1075/ aila.22.05lim

Meyerhoff, M. (2006). Introducing Sociolinguistics (pp. 352). Retrieved from British Library Cataloging in Publication Data database

Miles, M. B., Huberman, A. M., and Saldana, J. (2014). Qualitative Data Analysis: A Methhods Sourcebook $\left(\begin{array}{ll}3^{\text {rd }} & E d .\end{array}\right)$ California: SAGE Publications.

Romaine, S. (1994). Language in Society: An Introduction to Sociolinguistics. Oxford: Oxford University Press.

Romaine, S. (1995). Bilingualism (Second ed.). Oxford Blackwell.

Smith-Hefner, N. J. (2009). Language Shift, Gender, and Ideologies of Modernityin CentralJava Indonesia. Journal of Linguistic Anthropology, 19(1), 55-77. doi: 10.1111/j.15481395.2009.01019.x
Spolsky, B. (2003). Sociolinguistics. Oxford: Oxford University Press.

Undang-Undang Sistem Pendidikan National No.20 Tahun 2003

UNESCO. (1953). The Use of Vernacular Languages in Education. Monographs on Fundamental Education. Unesco. Paris. Retrieved from http://unesdoc.unesco.org/ images $/ 0000 / 000028 / 002897 \mathrm{eb}$. pdf

UNESCO. (2003). Language Vitality and Endangerment. Paper presented at the The International Expert Meeting on UNESCO Programme Safeguarding of Endangered Languages Paris. www.unesco.org/ culture/ich/doc/src/00120-EN. pdf

UNESCO. (2016). Mother Tongue Multilingual Education. Retrieved 27 June 2016, 2016, from http:// www.unesco.org/new/en / education/themes/strengtheningeducation-systems/languages-ineducation/multilingual-education/ Wei, L. (2008). Research Perspectives on Bilingualism and Multilingualism In L. Wei \& M. G. Moyer (Eds.), The Blackwell Guide to Research Methods in Bilingualism and Multilingualism (pp. 3-17). Malden, MA: Malden, MA: Blackwell Publishing Ltd. 